\title{
Effects of Oxytocin on Sperm Motility and In Vitro Fertilization in the Mouse
}

\author{
Thevin VongPRALUB and Fukashi KoyanAGI \\ Faculty of Agriculture, Kyushu Tokai University \\ Choyo-mura, Kumamoto-ken 869-14
}

(Received December 20, 1993)

\begin{abstract}
Motility and the acrosome-reacted rate of mouse spermatozoa, and the in vitro fertilization rate in oxytocin-supplemented media were investigated. Spermatozoa collected from the vas deferens and cauda epididymis were incubated in a medium containing $10^{-10} \mathrm{M}$ oxytocin for $5 \mathrm{~h}$. Although the percentage of motile spermatozoa decreased in the course of time, it remained significantly high except for $1 \mathrm{~h}$ after incubation when compared to the control. The percentage of hyperactivated spermatozoa was higher than in the control throughout the incubation period. There was also an increase in the percentage of acrosome-reacted spermatozoa at 1 , 3 and $5 \mathrm{~h}$ after incubation. The fertilizatiom rate in cumulus-free eggs (46\%) was lower than that of cumulus-intact eggs (83\%). When $10^{-12}, 10^{-10}$ and $10^{-8} \mathrm{M}$ oxy tocin were supplemented into the fertilization medium, the fertilization rates increased significantly to 63,73 , and $57 \%$, respectively. The present results suggest that oxytocin in the medium stimulates sperm motility and is effective for in vitro fertilization.
\end{abstract}

Anim. Sci. Technol. (Jpn.) 65 (8) : 695-700,1994

Key words : sperm motility, in vitro fertilization, oxytocin, mouse

It is known that oxytocin is secreted from neurohypophysis in mammals. Oxytocin also exists in the ovary ${ }^{4,13,14,32)}$, adrenal tissue ${ }^{21)}$, testis $^{21)}$ and central nervous system other than in the hypothalamus ${ }^{19)}$. The sources of oxy tocin in the ovary are granulosa cells ${ }^{12,24)}$ and the luteal cells derived from the granulosa cells ${ }^{27}$. It has been proposed that ovarian oxytocin supports luteolysis ${ }^{57}$ ) and is involved in steroidogenesis ${ }^{11}$. MAKIMURA et al. ${ }^{17)}$ have suggested that oxytocin has a beneficial effect on the in vitro development of early stage embryos in the mouse. In addition, it seems likely that oxytocin may affect eggs and spermatozoa before fertilization if oxytocin is present in the lumen of the female genital tract during the periovulatory period. This study was carried out in order to clarify the effects of oxytocin on the motility of spermatozoa and the in vitro fertilization rate.

\section{Materials and Methods}

Motility and acrosome reaction of spermatozoa: Mature male mice of the ddY strain were killed by cervical dislocation and the vas deferens and cauda epididymis were excised. After washing and cutting them into small pieces, they were incubated in modified Tyrode's solution, $T_{6}$ medium $^{25)}$, containing 4 $\mathrm{mg} / \mathrm{m} l$ bovine serum albumin (BSA) for the dispersion of spermatozoa at $37^{\circ} \mathrm{C}$ for $25 \mathrm{~min}$. Then the upper part of the sperm suspension was gently sucked up.

The sperm suspension was added to each 0.4 $\mathrm{m} l$ of $\mathrm{T}_{6}$ medium supplemented with $10^{-10} \mathrm{M}$ oxytocin (Bachem Inc. Torrance CA) and without oxy tocin (control) to give a final concentration of approximately $1 \times 10^{6}$ cells $/ \mathrm{ml}$. The 
spermatozoa were incubated at $37^{\circ} \mathrm{C}$ for $5 \mathrm{~h}$ under paraffin oil in a humidified atmosphere of $5 \% \mathrm{CO}_{2}$ in air. The motility and incidence of acrosome reaction of spermatozoa were evaluated at $1 \mathrm{~h}$ intervals. More than 200 spermatozoa were examined for the percentage of active motile spermatozoa and for the percentage of hyperactivated spermatozoa by phase-contrast microscopy. Spermatozoa showing a star-spin trajectory or a transitional trajectory with vigorous activity were identified as hyperactivated spermatozoa ${ }^{26)}$. For determining acrosome-reacted spermatozoa, more than 100 motile spermatozoa were examined under a phase-contrast microscope $(400 \times)$. The percentages of hyperactivated spermatozoa and acrosome-reacted spermatozoa in the entire sperm population were calculated, and data were analyzed using the paired $\mathrm{t}$-test after arcsine-transformation.

In vitro fertilization: Immature mice of the ddY strain (3 4 weeks of age) were superovulated with an intraperitoneal injection of 5 iu pregnant mare serum gonadotrophin (Serotropin, Teikoku Zouki Co., Tokyo), followed $48 \mathrm{~h}$ later by 5 iu human chorionic gonadotrophin (hCG; Gonatropin, Teikoku Zouki Co., Tokyo). The eggs were collected from the ampulla of the uterine tube $15 \mathrm{~h}$ after hCG injection. Some of the eggs obtained were transferred to the $\mathrm{T}_{6}$ medium containing $0.1 \%$ hyaluronidase (Type V, Sigma Chemical $\mathrm{Co}, \mathrm{St}$. Louis MO) so as to remove the cumulus cells.

$\mathrm{T}_{6}$ media with $15 \mathrm{mg} \mathrm{BSA} / \mathrm{ml}$ containing $10^{-6}, 18^{-8}, 10^{-10} \mathrm{M}$ and $10^{-12} \mathrm{M}$ oxytocin were prepared as the fertilization medium for cumulus-free eggs. The media without oxytocin for cumulus-intact eggs and cumulus-free eggs served as controls. The sperm suspension was prepared by the method described above and then spermatozoa were preincubated for capacitation at $37^{\circ} \mathrm{C}$ for $2 \mathrm{~h}$. A small amount of preincubated sperm suspension was added to $0.4 \mathrm{~m} l$ of each fertilization medium to give a final concentration of approximately $1.5 \times 10^{6}$ cells $/ \mathrm{m} l$. Then $4 \sim 10$ eggs were introduced into the sperm suspension under paraffin oil. The mixtures of spermatozoa and eggs were incubated at $37^{\circ} \mathrm{C}$ under $5 \% \mathrm{CO}_{2}$ in air. After $6 \mathrm{~h}$ of incubation, the eggs were examined for the presence of two pronuclei. For further confirmation of sperm penetration, the eggs were cultured in Hoppe and PIrTs's medium ${ }^{8)}$ for $24 \mathrm{~h}$ to examine their development to a 2-cell stage. Data were analyzed by the $\chi^{2}$-test.

\section{Results}

In the $10^{-10} \mathrm{M}$ oxytocin-supplemented group, the percentage of motile spermatozoa decreased in the course of time after the start of incubation. However, the degree of decresase was significantly less than that of the control except for $1 \mathrm{~h}$ after incubation (Fig. 1). The percentage of hyperactivated spermatozoa was significantly higher than in the control throughout the incubation period. There was also an increase in the percentage of acrosomereacted spermatozoa at 1,3 and $5 \mathrm{~h}$ after incubation.

The fertilization rate in cumulus-free eggs (46\%) was lower than that in cumulus-intact eggs $(83 \%)$. When media with various concen. trations of oxytocin were tested as a fertilization medium for cumuius-free eggs, fertilization rates in the $10^{-12}, 10^{-10}$ and $10^{-8} \mathrm{M}$ groups increased significantly, although the rates were significantly lower than those for cumulusintact eggs. Among the three concentrations of oxytcin, $10^{-10} \mathrm{M}$ oxytocin supported the maximal level of fertilization. Oxytocin at the concentration of $10^{-6} \mathrm{M}$ was not effective in supporting the fertilization of cumulus-free eggs (Table 1).

\section{Discussion}

It has been suggested that ovarian oxytocin in ruminants is involved in luteolysis via the positive feedback loop in which oxytocin and 

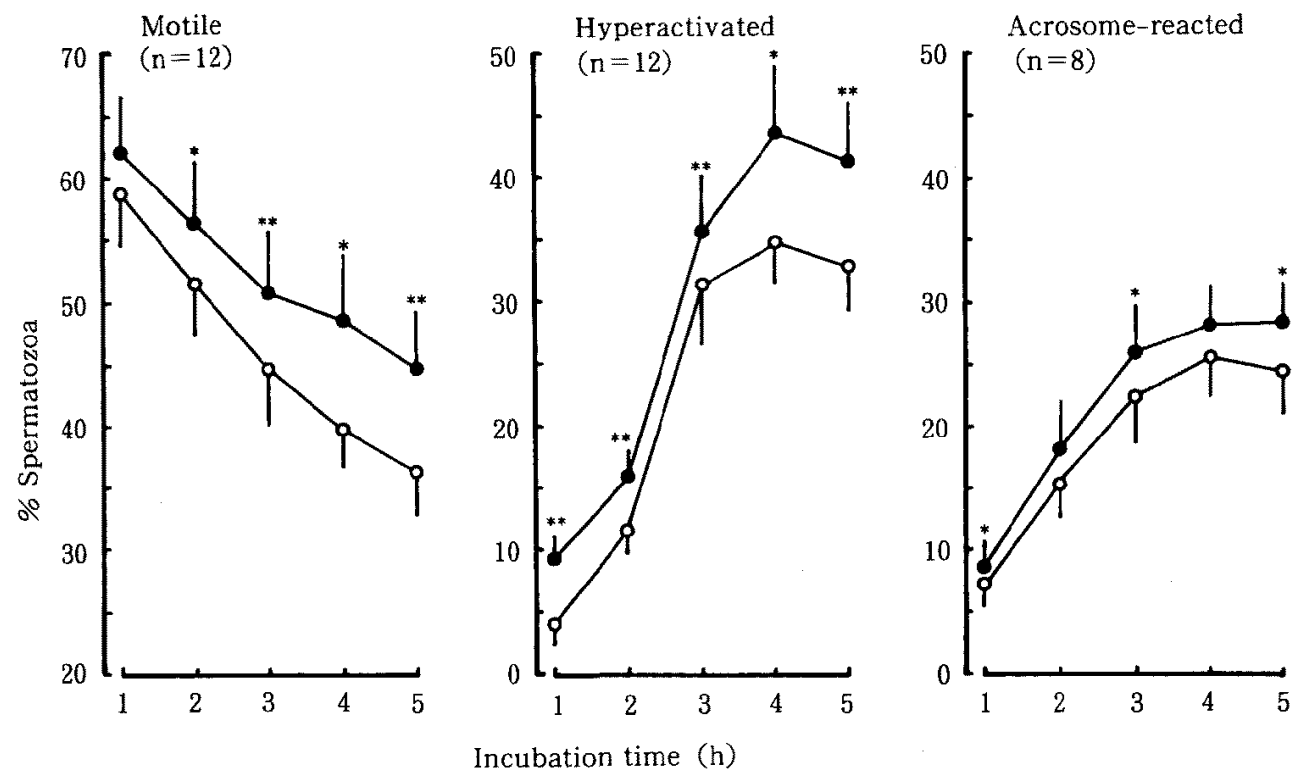

Fig. 1. Effect of oxytocin on the motility and acrosome reaction of spermatozoa. The percentages of hyperactivated spermatozoa and acrosome-reacted spermatozoa show the values in the entire population. Each value represents the mean $\pm \mathrm{SE}$. $\mathrm{O}-\mathrm{O}$ control. * $\mathrm{P}<0.05,{ }^{* *} \mathrm{P}<0.01$.

Table 1. Effect of oxytocin on fertilization in vitro

\begin{tabular}{lccc}
\hline Condition of egg & $\begin{array}{c}\text { Concentration of } \\
\text { oxytocin (M) }\end{array}$ & $\begin{array}{c}\text { No. of eggs } \\
\text { examined }\end{array}$ & $\begin{array}{c}\text { No. (\%) of eggs } \\
\text { fertilized }\end{array}$ \\
\hline Cumulus-intact & - & 246 & $204(83)^{\mathrm{a}}$ \\
Cumulus-free & - & 246 & $112(46)^{\mathrm{e}}$ \\
& $10^{-12}$ & 63 & $40(63)^{\mathrm{bc}}$ \\
& $10^{-10}$ & 182 & $133(73)^{\mathrm{b}}$ \\
& $10^{-8}$ & 149 & $85(57)^{\mathrm{cd}}$ \\
& $10^{-6}$ & 110 & $50(45)^{\text {de }}$ \\
\hline
\end{tabular}

a-e Values with different superscripts are significantly different $(p<0.05)$.

prostaglandin $F_{2 \alpha}$ are mutually reinforced ${ }^{5,7)}$. Oxytocin has also been detected in human follicular fluid ${ }^{28}$. In the mouse, the secretion of oxy tocin from cumulus cells during culture has been reported ${ }^{18)}$. This information suggests the presence of oxytocin in the female genital tract in the periovulatory period.

Mouse spermatozoa are stored in the lower isthmus before ovulation and are transported to the ampulla at the time of ovulation ${ }^{22)}$, in the same way as spermatozoa in other species ${ }^{3)}$. SMITH and YANAGIMACHI ${ }^{29}$ have reported that capacitation in hamster spermatozoa proceeds at a faster rate when mating occurs immediately after ovulation rather than shortly after the onset of estrus. ITo et al. ${ }^{10)}$ have suggested that ovulatory products stimulate the sperm transport from the caudal isthmus to the ampulla. Futhermore BRADLEY and Garbers ${ }^{2)}$ have shown that a factor(s) released from 
bovine cumulus cells stimulates sperm motility in vitro. The results of this study indicate that oxytocin in the medium supports the survival of spermatozoa, as well as the induction of sperm hyperactivation and the acrosome reaction. Therefore, oxytocin seems to be one of factors involved in the storage of spermatozoa in the lower isthmus and the transport of spermatozoa from the isthmus.

The present study shows that the removal of cumulus oophorus from the egg decreases the fertilization rate. This result supports many reports on other species ${ }^{6,15,16)}$ including the mouse $^{23)}$. As possible causes of the decreased fertilization rate, we can presume the zona pellucida hardening during culture and/or the modification of sperm receptors of the zona pellucida during the process of cumulus denudation as suggested by MochizuKI et al. ${ }^{20)}$, and ITAGAKI and TOYODA ${ }^{9)}$. In addition, cumulus cells stimulate the acrosome reaction of spermatozoa ${ }^{6}$, and the secretions from the cumulus cells increase sperm motility ${ }^{2)}$, supporting that cumulus cells have a beneficial effect on in vitro fertilization. In this study the oxytocin supplement increased the percentage of hyperactivation and acrosome reaction, and improved the fertilization rate of cumulus-free eggs. MAKImUra et al. ${ }^{18)}$ found that mouse cumulus cells secreted oxy tocin. These findings suggest the possibility that cumulus cells may secrete oxytocin which stimulates spcrmatozoa to support fertilization.

The mode of action of oxy tocin on spermatozoon is unclear. Both hyperactivation and the acrosome reaction of spermatozoa appear to be initiated by the influx of calcium through the plasma membrane ${ }^{30,31)}$. Furthermore, according to BATRA ${ }^{1}$, oxytocin-induced contraction of the myometrium is largely dependent on the influx of extracellular calcium. Therefore, it is probable that oxytocin action on the induction of sperm hyperactivation and acrosome reaction may occur via the process of calcium influx.

\section{References}

1) BAtra, S., Effect of oxy tocin on calcium influx and efflux in the rat myometrium. Eur. J. Parmacol., 120 : 57-61. 1986.

2) Bradley, M.P. and D.L. Garbers, The stimulation of bovine caudal epididymal sperm forward motility by bovine cumulus-egg complexes in vitro. Biochem. Biophys. Res. Commun., $115:$ 777-787. 1983.

3) Eisenbach, M. and D. Ralt, Precontact mammalian sperm-egg communication and role in fertilization. Am. J. Physiol., 262 : C1095-C1101. 1992.

4) Flint, A.P.F. and E.L. SHELdRick, Ovarian secretion of oxytocin is stimulated by prostaglandin. Nature, 297 : 587-588. 1982.

5) Flint, A.P.F. and E.L. SHELDRICK, Evidence for a systemic role for ovarian oxy tocin in luteal regression in sheep. J. Reprod. Fertil., 67 : 215225. 1983.

6) Fukui, Y., Effect of follicle cells on the acrosome reaction, fertilization, and developmental competence of bovine oocytes matured in vitro. Mol. Reprod. Dev., 26 : 40-46. 1990.

7) Hooper, S.B., W.B. WATKINS and G.D. Thorburn, Oxytocin, oxytocin-associated neurophysin, and prostaglandin $F_{2 \alpha}$ concentrations in the utero-ovarian vein of pregnant and nonpregnant sheep. Endocrinology, 119:25902597. 1986.

8) HoPPE, P.C. and S. PITTS, Fertilization in vitro and development of mouse ova. Biol. Reprod., 8: $420-426.1973$.

9) ITAGAKI, $Y$. and Y. TOYODA, Effects of prolonged sperm preincubation and elevated calcium concentration on fertilization of cumulus-free mouse eggs in vitro. J. Reprod. Dev., $38: 219-224.1992$.

10) Iто, M., T.T. SMiTh and R. YANAGiMaCHI, Effect of ovulation on sperm transport in the hamster oviduct. J. Reprod. Fertil., 93: 157-163. 1991.

11) Jarry, H., A. Einspanier, L. Kanngieber, M. Dietrich, L. Pitzel, W. Holtz and W. Wuttke, Release and effects of oxytocin on estradiol and progesterone secretion in porcine corpora lutea as measured by an in vivo microdialysis system. Endocrinology, $126: 2350-2358.1990$.

12) JungClas, B. and M.R. LuCK, Evidence for glanulosa-theca interaction in the secretion of oxytocin by bovine ovarian tissue. $\mathrm{J}$. 


\section{Effects of Oxytocin on Spermatozoa}

Endocrinol, 109 : R1-R4. 1986.

13) KHAN-Dawood, F.S. and M.Y. Dawood, Human ovaries contain immunoreactive oxytocin. J. Clin. Endocrinol. Metab., 57 : 1129-1132. 1983.

14) KHan-Dawood, F.S., E.L. Marut and M.Y. Dawood, Oxytocin in the corpus luteum of the cynomolgus monkey (Macaca fascicularis). Endocrinology, 115 : 570-574. 1984.

15) KiKuChI, K., T. NagaI, J. Motlik, Y. ShIOYA and $Y$. IZAIKE, Effect of follicle cells on in vitro fertilization of pig follicular oocytes. Theriogenology, $39: 593-599.1993$.

16) Kobayashi, K., D.L. Hill, C.M. Rothman, C.F. UNDERBERGER and S. OGAWA, Co-culture of subzonally microinseminated human oocytes with cumulus cells. Theriogenology, $39: 247$. 1993.

17) Makimura, N., K. Furuya, N. Ishikawa, T. Hoshihara, K. Tsubamoto, K. Seki and I. NAGATA, The effect of oxytocin on the development of mouse embryo. J. Fertil. Implant. (Tokyo), 9 : 194-196. 1992.

18) Makimura, N., K. Furuya, N. Ishikawa, T. Hoshihara, K. Tubamoto, K. Seki and 1 . NAGATA, The secretion of oxytocin and progesterone by mouse cumulus cells. J. Fertil. Implant. (Tokyo), 10 : 102-103. 1993.

19) Miaskowski, C., G.L. ONG and J. HALDAR, Cyclic variations in spinal cord levels of oxytocin and vasopressin during the stages of the rat estrous cycle. Endocrinology, 120 : 1685-1687. 1987.

20) MochizukI, H., Y. Fukui and H. ONo, Effect of the number of granulosa cells added to culture medium for in vitro maturation, fertilization and development of bovine oocytes. Theriogenology, 36 : 973-986. 1991.

21) Nicholson, H.D., R.W. Swann, G.D. Burford, D. C. Wathes, D.G. Porter and B.T. Pickering, Identification of oxytocin and vasopressin in the testis and in adrenal tissue. Regul. Pept., $8: 141-146.1984$.

22) OLDS, P.J., Effect of the $T$ locus on sperm distri- bution in the house mouse. Biol. Reprod., 2 : 91-97. 1970.

23) Pavlok, A. and A. McLaren, The role of cumulus cells and the zona pellucida in fertilization of mouse eggs in vitro. J. Reprod. Fertil., 29 : 91-97. 1972.

24) Plevrakis, I., C. Clamagirand and G. Pontonnier, Oxytocin biosynthesis in serumfree cultures of human granulosa cells. J. Endocrinol., 124 : R5-R8. 1990.

25) Quinn, P., C. BArros and D.G. WhitTingham, Preservation of hamster oocytes to assay the fertilizing capacity of human spermatozoa. J. Reprod. Fertil., 66 : 161-168. 1982.

26) Robertson, L., D.P. Wolf and J.S. TASH, Temporal changes in motility parameters related to acrosomal status : Identification and characterization of populations of hyperactivated human sperm. Biol. Reprod., 39 : 797-805. 1988.

27) Rodgers, R.J., J.D. O'SheA, J.K. Findlay, A.P.F. FLINT and E.L. SHELDRICK, Large luteal cells the source of luteal oxytocin in the sheep. Endocrinology, $113: 2302-2304.1983$.

28) SChAEFFER, J.M., J. LiU, A.J.W. HSUEH and S.S.C. YEN, Presence of oxytocin and arginine vasopressin in human ovary, oviduct, and follicular fluid. J. Clin. Endocrinol. Metab., 59 : 970-973. 1984.

29) Smith, T.T. and R. YanagimaCHI, Capacitation status of hamster spermatozoa in the oviduct at various times after mating. J. Reprod. Fertil., 86 : 255-261. 1989.

30) TASH. J.S. and A.R. MEANS, Cyclic adenosine 3', 5' monophosphate, calcium and protein phosphorylation in flagellar motility. Biol. Reprod., 28 : 75-104. 1983.

31) Wassarman, P.M., The biology and chemistry of fertilization. Science, 235 : 553-560. 1987.

32) Wathes, D.C., R.W. SwanN, S.D. BiRkeTt, D.G. PORTER and B.T. PICKERING, Characterization of oxytocin, vasopressin, and neurophysin from the bovine corpus luteum. Endocrinology, 113 : 693-698. 1983. 


\title{
In vitroにおけるマウス精子の運動性および 受精率に及ぼすオキシトシンの効果
}

Thevin VongPralub *小柪 深

九州東海大学農学部, 熊本県長陽村 869-14

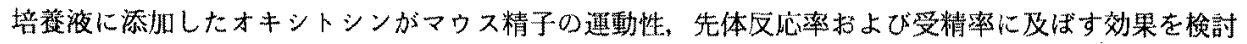

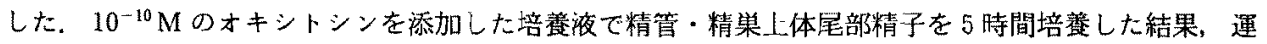
動精子の割合は時間の経過とともに低下したが，培養開始後 1 時問目以降，対照に比べて有意に高い值 を維持した。ハイパーアクチベーションを起した精子の割合は，培養期間を通して有意に高く，先体反 応率は，培養開始後 $1 ， 3$ および 5 時間に有意に高い值を示した，卵丘除去卵子の受精率は（46\%），瞓

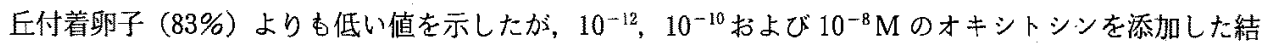
果, 眨丘除去卵子の受精率はそれぞれ 64，73，57\%に有意に増加した。これらの結果から，オキシトシ ンは in vitroにおいて精子の運動性を刺激し，受精に有効な作用を及ぼすもの之推察された。
\end{abstract}

日畜会報, $65(8): 695-700,1994$ 